\title{
A Case Study for a Zero Impact Building in Belgium: Mondo Solar-2002
}

\author{
Shady Attia*
}

\begin{abstract}
This paper presents the Solar-2002 zero impact renovation project in Belgium. Its characteristics are based on fundamental principles taking advantage of natural resources by diverting the sun shine and rain in the building design. The building has been renovated aiming to achieve principals of occupant health and comfort, energy efficiency, renewable energy production, resource conservation and reduction of environmental impacts. The paper reviews the design concepts including the passive and active strategies and compare building actual performance to actual monitoring results. Innovations related to architectural design, building system performance and simulation are presented. Results show that the house achieved energy and carbon neutral balance, closed water cycle and almost a cradle to cradle building material cycle. However, monitoring results shows the difficulty to maintain optimal thermal comfort during extreme summer and winter periods. Achieving the environmental zero impact objectives is not economically feasible without the subsidies from the federal and regional government.
\end{abstract}

Keywords: Solar-2002, Zero impact, Renovation, Housing, Monitoring, Belgium

\section{INTRODUCTION}

Belgium is an industrialized nation with one of the largest ecological footprints in the world. Every household constructed in Belgium damages the environment through the energy it purchases (average end-use $200 \mathrm{kWh} / \mathrm{m}^{2}$ ) [1], the water and materials it uses, the kilometres it travels, the food it consumes and the waste it disposes. All of these impacts when calculated can be used to define the ecological footprint of individual households [2].

\subsection{Ecological footprint in Belgium}

Compared to the average ecological footprint of 2.2 hectares, Belgium is ranked 13th out of 150 countries. Belgium's ecological footprint is 5.6 hectares, which is over twice the world average and over three times a sustainable ecological footprint (1.8 hectares). Thus, the Belgian lifestyle implies two additional earths like planets to live on. For the year 2008, Belgium's ecological footprint was broken down into four sectors: $20 \%$ for food, $20 \%$ for mobility, $25 \%$ housing and $35 \%$ miscellaneous [3].

\subsection{Mondo - Solar 2002}

Addressing the footprint of the housing sector and aiming to create a pilot project for a zero impact household, the non-profit organization Mondo started retrofitting an existing single family housing. The main focus was concentrating on the three largest environmental impacts of a typical household: greenhouse gas (GHG) emissions, water consumption and

\footnotetext{
* Corresponding author.

E-mail address: shady.attia@uclouvain.be

Article history

Received February17, 2011

Accepted May 15, 2011

C2011 SUSB Press. All rights reserved.
}

material consumption [4] (Fig.1). The impact is by far the most significant in the housing sector. However, the project hypothesis defies the Belgian weather limitations claiming the possibility to create a zero impact house by diverting local resources sustainably [5]. The house is located in Berlaar, a small village $31 \mathrm{~km}$ north-east of Brussels and located in the province of Antwerp, $\left(51,07^{\circ}\right.$ longitude east, $4,39^{\circ}$ latitude north). Fortunately, the authorities such as the Flemish Regional Council encourage the effort to reduce buildings impact with a special focus on GHG emissions and water. For example the authority, influenced by the allocation plan that aims a reduction of $7.5 \%$ of GHG emissions, subsidies solar water heaters and photovoltaic panels [6]. Also the authorities encourage the use of green roofs, rain water and water filtration systems. Among the three resources of energy, water and materials the study's conclusions relate to managing the three resources use and planning to benefit of their renewable cycles.

\subsection{Methodology and objectives}

The main objective of the renovation project was to achieve a state of ecological building neutrality and occupant thermal comfort. The house should be energy efficient, integrating bioclimatic architectural concepts, and supplied through renewable energy resources. The resources consumption was documented through extensive monitoring and life cycle assessment calculations [7, 8]. More than 52 metering points were used between 2006 and 2009 for solar radiation, solar collectors, temperatures, humidity, water quality, water storage, $\mathrm{CO}_{2}$ emissions, electricity consumption, heat-pump and PV generation [9]. Also dissemination activity took place to support knowledge transfer and market adoption of zero impact buildings on a national and international level through 
Shady Attia is an architectural engineer working as a scientific researcher at the Catholic University of Louvain in Belgium. He is also a member of the International Energy Agency Task 40 Team: Towards Net Zero Energy Buildings. This team is studying current net-zero, near net-zero and very low energy buildings and to develop a common understanding, a harmonized international definitions framework, tools, innovative solutions and industry guidelines. As registered architect, landscape architect and LEED accredited professional, he is working currently on completing his $\mathrm{PhD}$ in Architectural Engineering on the topic of building simulation for zero energy buildings looking at the potential impacts of simulation tool on the decision making of zero energy buildings design at the Catholic University of Louvain in Belgium.

presentations and publications. Thus the Solar-2002 renovation was based on four major criteria:

(1) Energy neutral, (2) water neutral, (3) $\mathrm{CO}_{2}$ neutral material life cycle and (4) occupant thermal comfort

\section{DESCRIPTION OF THE CASE STUDY}

Belgium's climate is generally moderate, with few extremes in temperature either in summer or winter. The climate is temperate and generally cloudy and rainy. Average monthly temperatures are lowest in December and January, when they fluctuate around $6^{\circ} \mathrm{C}$, and highest in July and August,

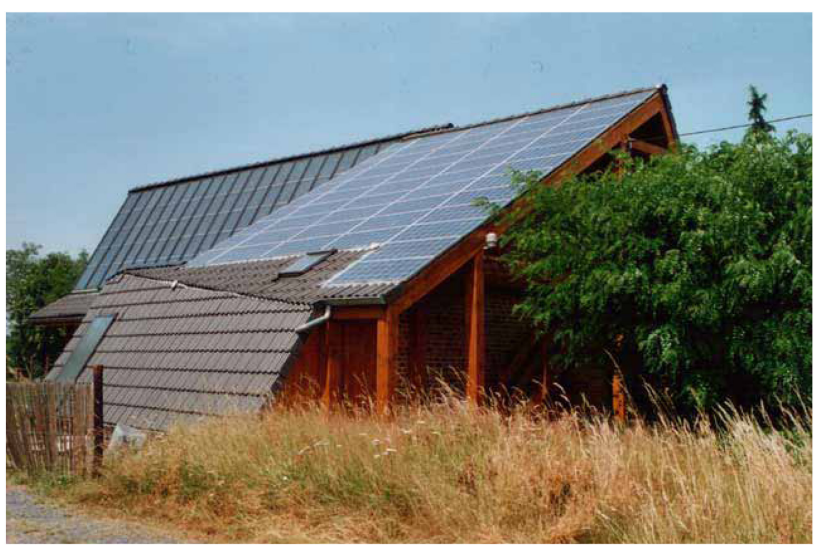

Fig.1 View of the PV and solar thermal roof of the building after the retrofit [4]

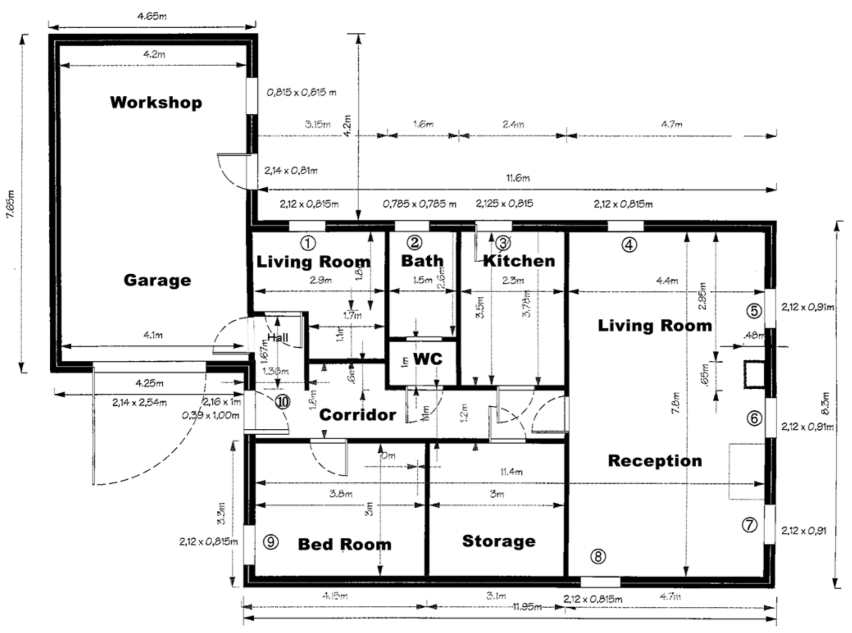

Fig.3 First floor plan when they fluctuate around $23^{\circ} \mathrm{C}$. Figure 2 gives the main features of the climate during the summer season and the winter season and the winter season for the site of the Solar-2002 building.

\subsection{Concept:}

The Solar 2002 dwelling is a two storey free standing house, built on a rectilinear site that faces a town road. The ground floor is a $100 \mathrm{~m}^{2}$ rectangle that is reduced to be $90 \mathrm{~m}^{2}$ in the first floor due to the pitched roof. The living and sleeping activities are located on the ground floor and the working areas on the first floor. There is a small atelier above the garage. The spatial organization of activities is demonstrated in Fig. 3 and 4. The house is built on a site with an east-west orientation (Fig.5). Sleeping rooms are facing the north-east direction. The south facade has the most openings allowing solar passive heating. During the summer season the windows orientation allows cross ventilation for cooling avoiding overheating periods.

\section{Passive skin}

The building skin performance is optimised through several passive strategies. Insulating the building envelope followed

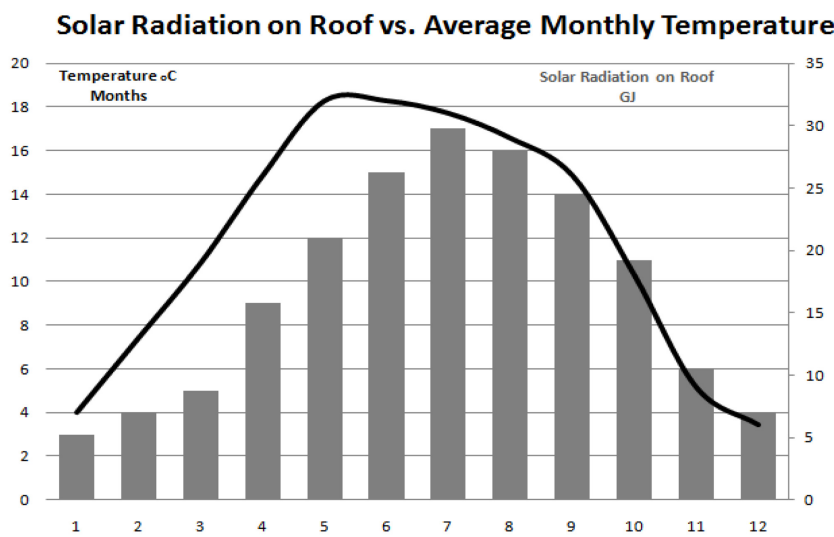

Fig.2 Main features of the climate during the summer season and winter season in Berlaar

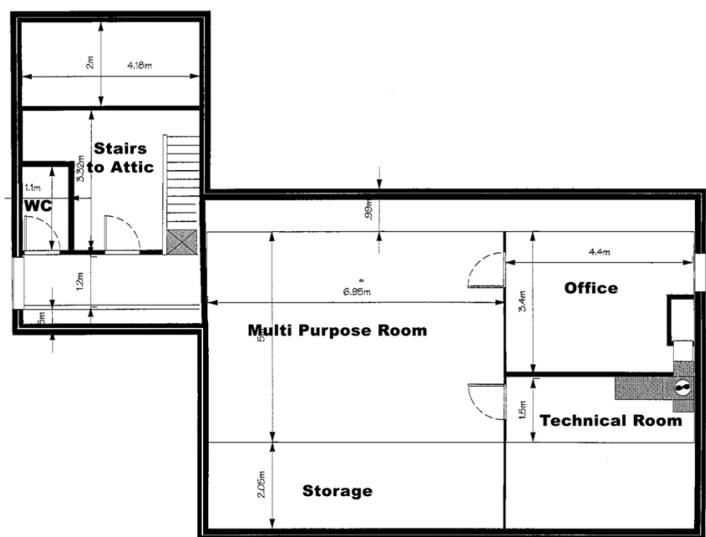

Fig.4 Second floor plan 
the passive house principles [10]. The walls combination consists of brick masonry, cavity, chipboard, mineral wool of $0,11 \mathrm{~m}$ and gypsum. The roof is a bituminized wood fibre panel with $0.23 \mathrm{~m}$ cellulose insulation, cavity and gypsum. The envelope properties are described in Table 1 . Another strategy was sealing the building envelope to prevent air leakage. Since the building is situated in an agrarian windy land it was necessary to seal all opening to reach 0.6 $\mathrm{ACH}$ at $50 \mathrm{~Pa}$. Further, the roof has seasonal shading geometry, so that south windows would be shaded in summer. Also exterior shutters are installed for South and West facing windows.

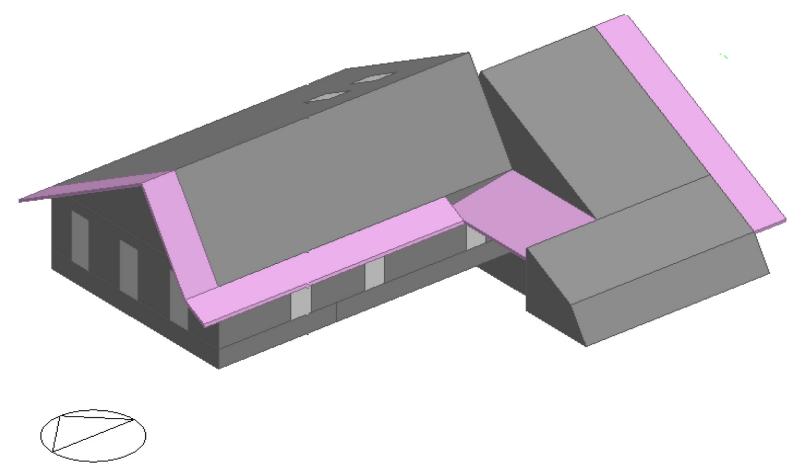

Fig.5 The building model in Design Builder

\section{Active skin}

The building envelope, particularly the pitched roof, is used extensively for hybrid solar thermal and electricity generation (Fig.1). In fact, 3400 hours per year are below $18^{\circ} \mathrm{C}$. Therefore, the south inclination of the roof is fully used for space heating, water heating and electricity generation. In contrast to traditional free standing housing, the roof has major functions. For space heating, two systems feed an
850 litre central thermal-storage tank (SOLUS II), first a Thermal Solar Air Collector (TSAC) of $36 \mathrm{~m}^{2}$ and secondly a water-water ground heat pump. The ground heat pump $\left(6 \mathrm{~kW}_{\text {th }}\right.$ and $1,3 \mathrm{~kW}_{\mathrm{e}}$ ) benefits from a water reservoir underground where the heat generated during summer is used to warm the ground while during winter the heat flux is used to heat the building spaces. The hot water accumulated in the tank is used in radiators and radiant floor heating. For domestic hot water (DHW) a $2 \mathrm{~m}^{2}$ heat pipe is feeding a 150 litre boiler. For electricity generation a PV/Thermal system of $36 \mathrm{~m}^{2}$ generates electricity of $5 \mathrm{~kW}$ peak. Heat is recovered from behind the PV array and circulated with a fan (Fig.6). It must be noted here that due to the experimental nature of the project and in order to achieve the energy independence, the house included many hybrid and complex technical installations.

\section{Water management}

In Berlaar, the average annual rainfall water per year is $780 \mathrm{~mm}$. This means that the average annual rainfall volume is beyond the occupants need (78000 litres). The house has two water cycles. The first water cycle stores the roof runoff in a central water tank. The tank feeds showers and toilets for flushing and simultaneously some volumes gets filtered and become safe potable water. The second water cycle treats the sewage. The sewage (black and grey water) is treated passing through three successive tanks, each 1200 litre, with filtering systems. The final filtered water is processed generating solid waste and clear water. The water feeds in a bio-cleaning lake and the solid waste is mixed back in the soil (Fig.7).

\section{Sustainable materials}

The original building structure has concrete floors and brick masonry walls. The new plan took advantage of the existing structure and renovated the building to be expected

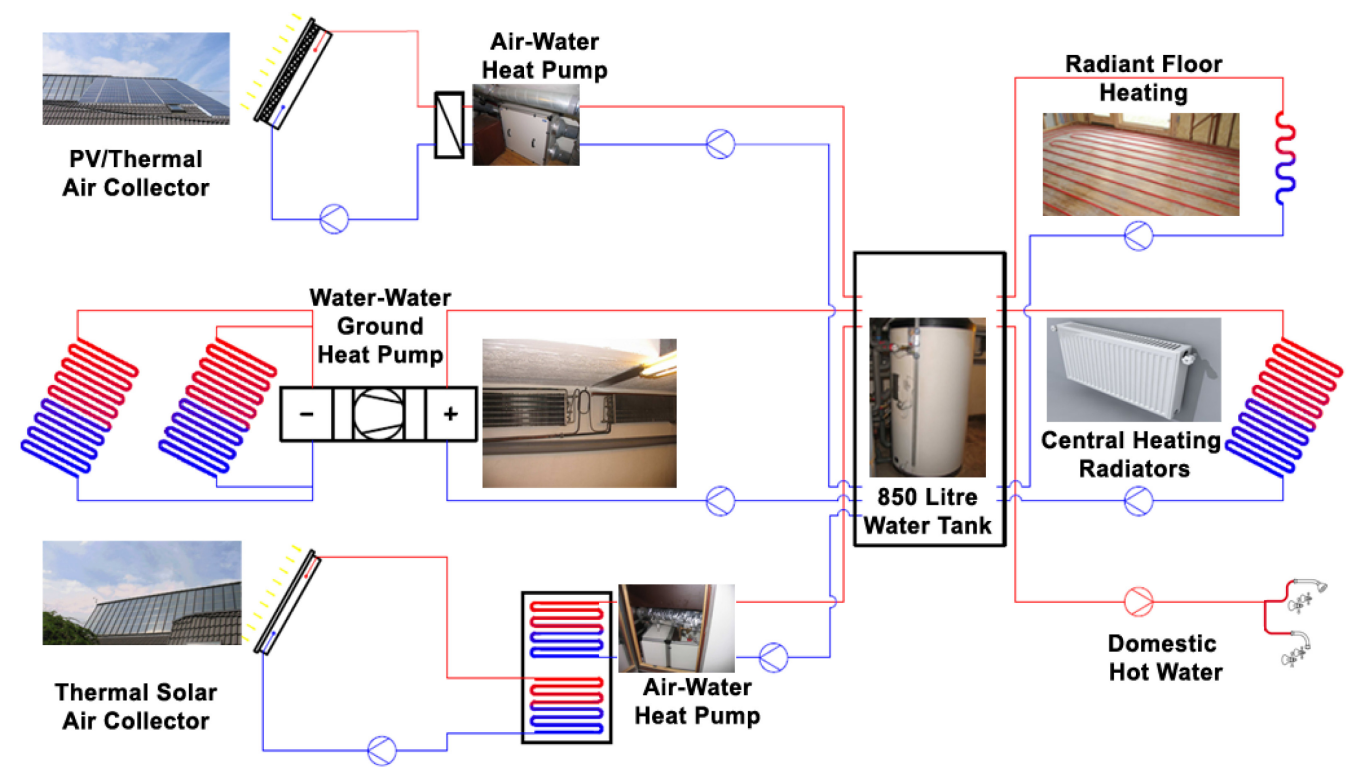

Fig. 6 Scheme for the active system installations 
Table 1 Solar-2002 construction details and installations characteristics

\begin{tabular}{|c|c|c|c|}
\hline Building Description & Solar 2002 & Solar Systems & Solar 2002 \\
\hline Shape & Rectangular ( $12 \mathrm{~m} \times 8 \mathrm{~m})$ & Azimuth & $0^{\circ}$ \\
\hline Heated Volume & $390 \mathrm{~m}^{3}$ & Avg. sunshine (Horizontal) & $2,55 \mathrm{kWh} / \mathrm{m}^{2}$.day \\
\hline Wall area, Floor area & $120 \mathrm{~m}^{2}, 168 \mathrm{~m}^{2}$ & TSAC Tilt & $60^{\circ}$ \\
\hline Glazing Fraction & S: $21 \% ; E: 4 \% ; W: 11 \% ; N ~ 4 \%$ & TSAC Area & $36 \mathrm{~m}^{2}$ \\
\hline Windows U-Value & $0.5 \mathrm{~W} / \mathrm{m}^{2} \mathrm{~K}(\mathrm{DG})$ & PV/Thermal Tilt & $30^{\circ}$ \\
\hline Exterior Wall U-Value & $0.10-0.35 \mathrm{~W} / \mathrm{m}^{2} \mathrm{~K}$ & PV/Thermal Area & $36 \mathrm{~m}^{2}$ \\
\hline Roof U-value & $0.16 \mathrm{~W} / \mathrm{m}^{2} \mathrm{~K}$ & Heat Pipe Tilt & $60^{\circ}$ \\
\hline Floor U-value & $0.25 \mathrm{~W} / \mathrm{m}^{2} \mathrm{~K}$ & Heat Pipe Area & $2 \mathrm{~m}^{2}$ \\
\hline Global U-value & $0.53 \mathrm{~W} / \mathrm{m}^{2} \mathrm{~K}$ & PV yield (average) & $4500 \mathrm{kWh}, 4.5 \mathrm{kp}$ \\
\hline
\end{tabular}

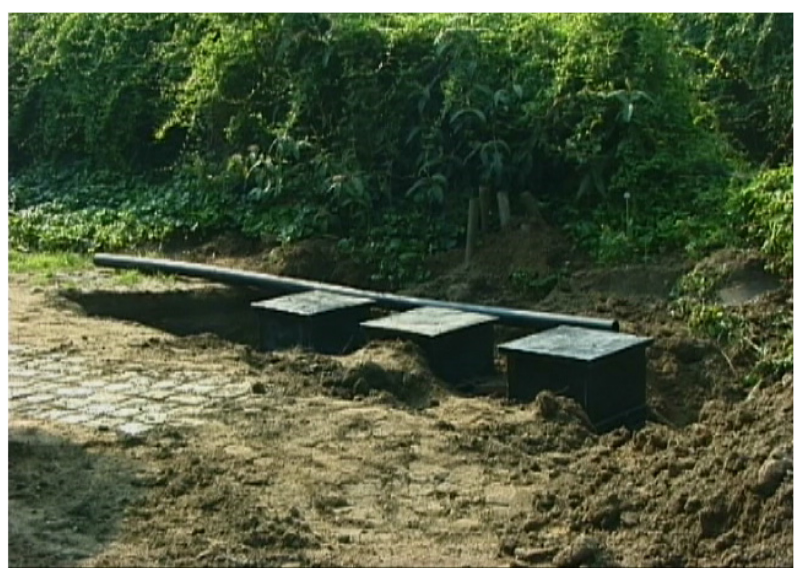

Fig.7 Water sewage treatments tanks

to last for 60-100 years. Building materials for renovation are selected based on three criteria: The first criterion is the low embodied energy and the second is the local availability to avoid long transportation distances. The third criterion is the ability for up cycling or biodegradation. The final material selection was in favour of FSC certified and locally grown wood (Condroz Area), including chestnut and oak trees. The selected insulation material is produced from recycled cellulose. The construction carbon calculator was used to calculate the $\mathrm{CO}_{2}[11]$.

\subsection{Construction details:}

The renovation process was based on adding an insulation layer from inside the building. The duct work for air and water lines was integrated with the insulation work. A ventilation system with heat recovery was installed to supply fresh air to the bedrooms and re-circulated air to the living room. Then, the external envelope was installed integrating all the solar panels in coordination with electrical and plumbing work.

\section{RESULTS}

A three phase energy analyzer was installed to quantify the energy consumption. Also the building energy bills were collected since 2006. Additionally, a set of data loggers (PT100- Class A) was installed with temperature sensors. The monitoring results were collected between 2006 and 2009.

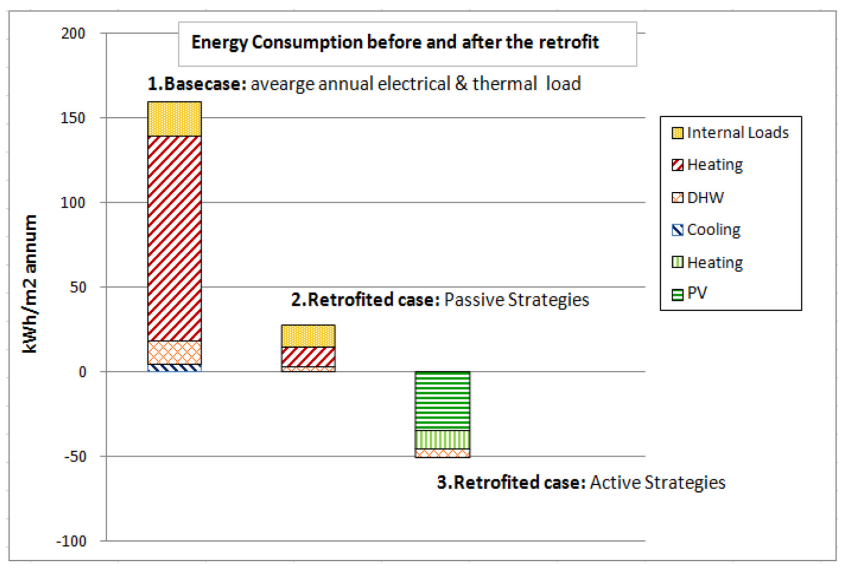

Fig.8 Energy consumption before and after the retrofit

\subsection{Carbon/energy neutral}

The house does not produce any $\mathrm{CO}_{2}$ and there is no burning process associated with the daily building use. Considering the energy consumption the Solar 2002 is energy dependent on a yearly basis. For calculating the energy neutrality the study adopted the International Energy Agency (IEA) Definition of Net Zero Energy Buildings (NZEBs). The IEA Definition states that a NZEB is a grid connected and energy efficient building that balances it total annual energy needs by on-site generation [12]. The house benefits from the solar radiation all over the year with plus generation that is fed to the grid. The generated thermal and electrical energy during the sunny season creates sufficient power to equalize the energy consumption on an annual basis. Monitoring results proof that the passive strategies saved yearly 90 GJ or $79 \%$ of the consumed primary energy for a typical reference house [9]. Also the house saves in average 4 ton or $68 \%$ of $\mathrm{CO}_{2}$ emissions yearly. The life cycle calculation proofs that the building will save up to 200-240 ton $\mathrm{CO}_{2}$ emission over a period of 50 years, excluding the embodied energy, if compared with similar house with a usage heating of average $23000 \mathrm{kWh}$ per year on natural gas.

\subsection{Water neutral}

The house is fully water independent and can stay off-pipe. A maximum use of rainwater was achieved. The water cycle was closed and the excess water was discharged and 


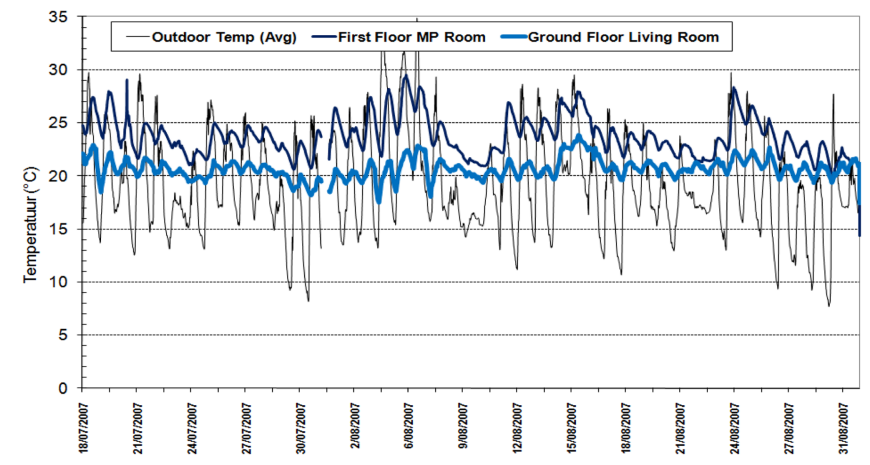

Fig.9 Outdoor and indoor temperature during 15 July - 31 August 2007

treated biologically on site.

\subsection{Material neutral}

The renovation process used ecological materials with low embodied energy. The used materials are biodegradable and can be easily processed by nature. The material life cycle was calculated for 100 year. The used materials had a zero embodied energy taking into account that the surplus energy generated onsite will compensate the extraction, manufacturing and transportation costs.

\subsection{Thermal comfort}

The monitoring results show that the thermal comfort was not guaranteed in all the house spaces. Figure 9 and 10 show the monitored temperatures in the living room (ground floor) and the multipurpose room (first floor). In the ground floor, it was not possible to guarantee comfortable temperatures. During winter it was difficult to keep the $20^{\circ} \mathrm{C}$ range and during summer the temperatures exceeded often the $25^{\circ} \mathrm{C}$ range [9]. In the first floor, thermal comfort was more difficult to achieve specially during summer because spaces witnessed long overheat periods. Also the monitoring indicates humidity problems influenced by the low airflow rate. Additionally, the three years monitoring period revealed another important finding. The building indoor quality (IAQ) was not well maintained. The recorded temperatures, humidity ratios and $\mathrm{CO}_{2}$ levels were high.

\section{DISCUSSION}

The aim of the paper was to present a pilot project that embraces the zero impact principles. In fact, the Solar 2002 house succeeded to achieve energy and carbon neutral balance, closed water cycle and almost a cradle to cradle building material cycle. However, the study revealed other important aspects that should be considered in our quest towards reaching zero impact buildings.

One of those aspects is comfort. Despite the occupant's satisfaction with building thermal comfort we found their feedback biased. In fact, according to the Belgian comfort standard the building could not guarantee good thermal comfort conditions, both in winter and in summer. Even applying night cooling did not solve the overheating problems during summer. Also we suggest conducting additional

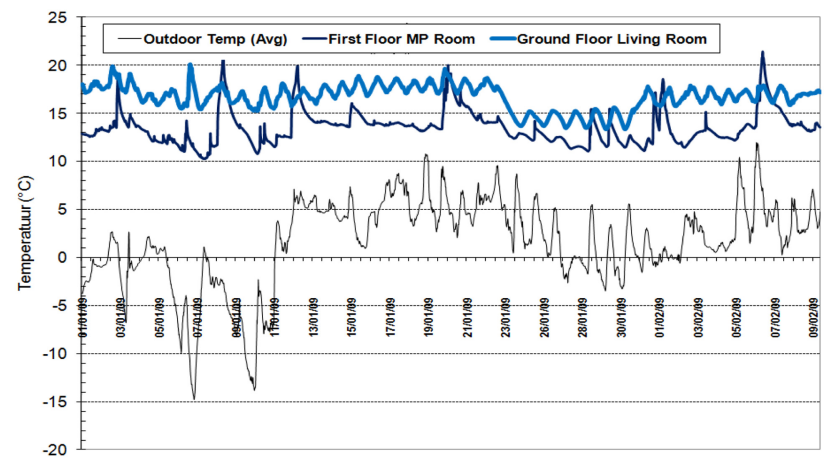

Fig.10 outdoor and indoor temperature during 1 January - 09 February 2009

detailed examination for the IAQ in the Solar 2002 house.

Another aspect that requires attention is the energy storage and grid connection. The house highlighted the importance of solar thermal storage. Heat was stored on a daily basis using the thermal storage tank or on a seasonal basis using the ground. However, that thermal heat storage could not meet the building loads requirements. On the other side, without being connected to the electricity grid the building couldn't be energy neutral. In fact, the implications of grid dependence and the influence of PV on the grid are important issues to achieve zero impact building. It might be interesting to look at those problems from an urban community scale involving several housing units and looking for central collective solutions.

Despite that the Solar 2002 could not achieve the carbon neutrality without technology; the technology used was too complex. Several systems were installed with a combination of diverse elements for thermal and electric. A zero impact building should be simple, operable and does not require expertise to run the house. Another disadvantage of those technologies is their high cost. In fact, the payback for all these installations is longer than 20 years which make them economically not rewarding.

Finally, the building performance could not be verified without monitoring and calculations. Monitoring and calculations must become part of any zero impact initiative. For this project monitoring was difficult since it is not done often. Also the life cycle analysis calculations are not standardized which make it difficult to compare and evaluate zero impact buildings [13].

\section{CONCLUSION}

The final building renovation allowed meeting the initial zero impact objectives. The renovation of Solar 2002 house has neutralized its largest environmental impacts in regard to energy, water and materials. This was thanks to the persistence of the building owner who insisted from the beginning to work on closing the resources cycles. Thus with a few architectural interventions the building almost reached its objective. However, without the use of renewable technology such as PV systems, solar panels and the geothermal installations the building could not achieve a zero impact. This could only be done through the financial 
aid and subsidies provided by the regional government and local province. The next step of this work will focus on more detailed examination of the building performance and occupant comfort through the building performance simulation in comparison with the monitoring data.

\section{ACKNOWLEDGEMENTS}

Thanks to the owner Guido De Couvreur who provided all information to conduct this study. The Solar 2002 house is the result of the group collaboration and financing of ELECTRABEL, VITP NV, Flemish Region, Antwerp Province, Berlaar municipality and the owner of the house.

\section{REFERENCES}

[1] Hens, H., Verbeeck, G. and Verdonck, B., "Impact of energy efficiency measures on the $\mathrm{CO}_{2}$ emissions in the residential sector, a large scale analysis," Energy and Building, Vol. 33, No. 3, 2001, pp.275-281.

[2] Malin, N., "Counting Carbon: Understanding Carbon Footprints of Buildings," Environmental Building News, July 1, 2008.

[3] Europe 2008 - The Ecological Footprint - <URL:http://www. footprintnetwork.org/en/index.php/GFN $>$ 2011, [Accessed 10 March 2011]

[4] Mondo vzw., Solar 2002: Zero balance energy house, in a bio-ecologically acceptable way, URL:http://www.mondo.be/ nieuw/engels/solar_2002_en_algemeen.html, 2009, [Accessed 10 November 2009].

[5] Attia, S., "Towards a Definition of Zero Impact Buildings,"
Sustainable Buildings CIB Conference, Maastricht, the Netherlands, 2010.

[6] Wittoeck, P., Belgian National Allocation Plan for $\mathrm{CO}_{2}$-emission allowances 2008-2012, Europe Energy, 2006, <URL:http:/www. climateregistry.be/fr/DOCS/BE\%20Belgian\%20NAP\%2020082012\%20consolidated\%2020060922.pdf> 2009, [Accessed 1 November 2009].

[7] Cole, R., "Emerging trends in building environmental assessment methods," Building Research \& Information, Vol. 26, No. 1, 1998, pp.3-16.

[8] Bryan, H., Trusty, W., "Developing an Operational and Material $\mathrm{CO}_{2}$ calculation protocol for buildings," Sustainable Buildings CIB Conference, Melbourne, Australia, 2008.

[9] Desmedt, J., Van Bael, J., "VEA-Demonstratieproject, Mondo bio-ecologische nulbalansenergiewoning te Berlaar," Report, VITO NV, Boretang, 2009.

[10] Passiefhuis Platform Belgium, <URL:http://www. passiefhuisplatform.be $>2009$, [Accessed 5 March 2011].

[11] Construction Carbon Calculator, BuildCarbonNeutral.org - A $\mathrm{CO}_{2}$ calculator for your whole building project, <URL: http:// buildcarbonneutral.org $>2011$ [accessed March, 2011].

[12] IEA-SHC Task 40, Towards Net Zero Energy Solar Buildings, Montreal, 2009.

[13] Attia, S., and De Herde, A., "Towards a Definition for Zero Impact Buildings," Sustainable Buildings CIB Conference, Maastricht, Netherlands, 2010. 